\title{
A Study on the Cultivation of College Students' Innovation and Entrepreneurship in the Internet Plus
}

\author{
Yongcheng Wang ${ }^{1, a}$, Zexing $\mathrm{Li}^{2, \mathrm{~b}}$, Changchen Zhang ${ }^{3, \mathrm{c}}$ \\ ${ }^{1,2,}$ College of Automobile \& Architectural Engineering, Beihua University, China \\ a29970991@qq.com,, $1007691051 @ q q . c o m,{ }^{c} 729495284 @ q q . c o m$
}

Keywords: Internet plus; Innovation; Entrepreneurship; Training

\begin{abstract}
Internet plus" era of the arrival of more and more industries, subversion of the original entrepreneurial thinking and ideas, the students in school during the innovation and entrepreneurial ability to cultivate, is to solve the "Internet plus" era This paper analyzes the characteristics of college students 'innovation and entrepreneurship activities in the era of "Internet plus" and the quality ability of college students' innovation and entrepreneurship, and combines the characteristics of innovation and entrepreneurship under the background of "Internet plus", To explore the basis of innovation base construction, to achieve the exchange of credits, improve the construction of teaching staff and the establishment of student enterprises two-way evaluation system to improve students innovative entrepreneurial ability development strategy, aims to "Internet plus" era of innovation and entrepreneurship ability Process, so that students focus on "Internet plus" innovative business thinking to Develop.
\end{abstract}

\section{Introduction}

On March 5, 2015, Premier Li Keqiang put forward the "Internet plus" action plan in the government work report made at the Third Session of the 12th National People's Congress. Since then, "Internet plus" as a national strategy for the future development of countries in various areas pointed out the direction. This major strategic initiative aims to use the Internet to accelerate the transformation and upgrading of traditional industries and build a new impetus to China's economic upgrading. The so-called "Internet plus" refers to the process of the integration, application and deep integration of the new generation of information technology (including mobile Internet, cloud computing, Internet of Things, large data, etc.) in the economic and social life departments Will have a huge, far-reaching and widespread impact on the human economy and society. The Internet has become a new tool for public entrepreneurship and innovation. Students are the young generation who master these new technologies, new skills and dare to innovate and challenge new things. "Internet plus" brings new development opportunities for college students' practice innovation and the entrepreneurship [1].

\section{The Development of Contemporary "Internet plus" Era of the Characteristics}

China Internet Network Information Center recently released the "China Internet Development Statistics Report" shows that as of December 2016, the scale of China's Internet users reached 731 million, equivalent to the sum of the population in Europe, the total number of new users 4299 million [2-3]. China's Internet users this year, the scale of development shown in Fig. 1. Chinese mobile Internet users reached 695 million scale, the proportion reached 95.1\% [4-6].

The steady growth of new netizens and the transformation of the original PC users to accelerate the common drive the scale of mobile phone users continue to expand. On the one hand, the convenience of mobile Internet access, reducing the use of the Internet threshold, is still an important force to promote the growth of new Internet users. In the first half of 2016, China's new Internet users in the scale of mobile phone users to 13.1 million people, accounting for $61.0 \%$ of new Internet users [7-8]. On the other hand, mobile Internet application services continue to enrich, and people's work, life, consumption, entertainment needs closely fit, and promote the PC users 
continue to quickly penetrate the mobile side. In the first half of 2016, 23.55 million new mobile Internet users from the original PC users in the conversion, the scale of the end of 2015 increased by 120.2 million [9-10].

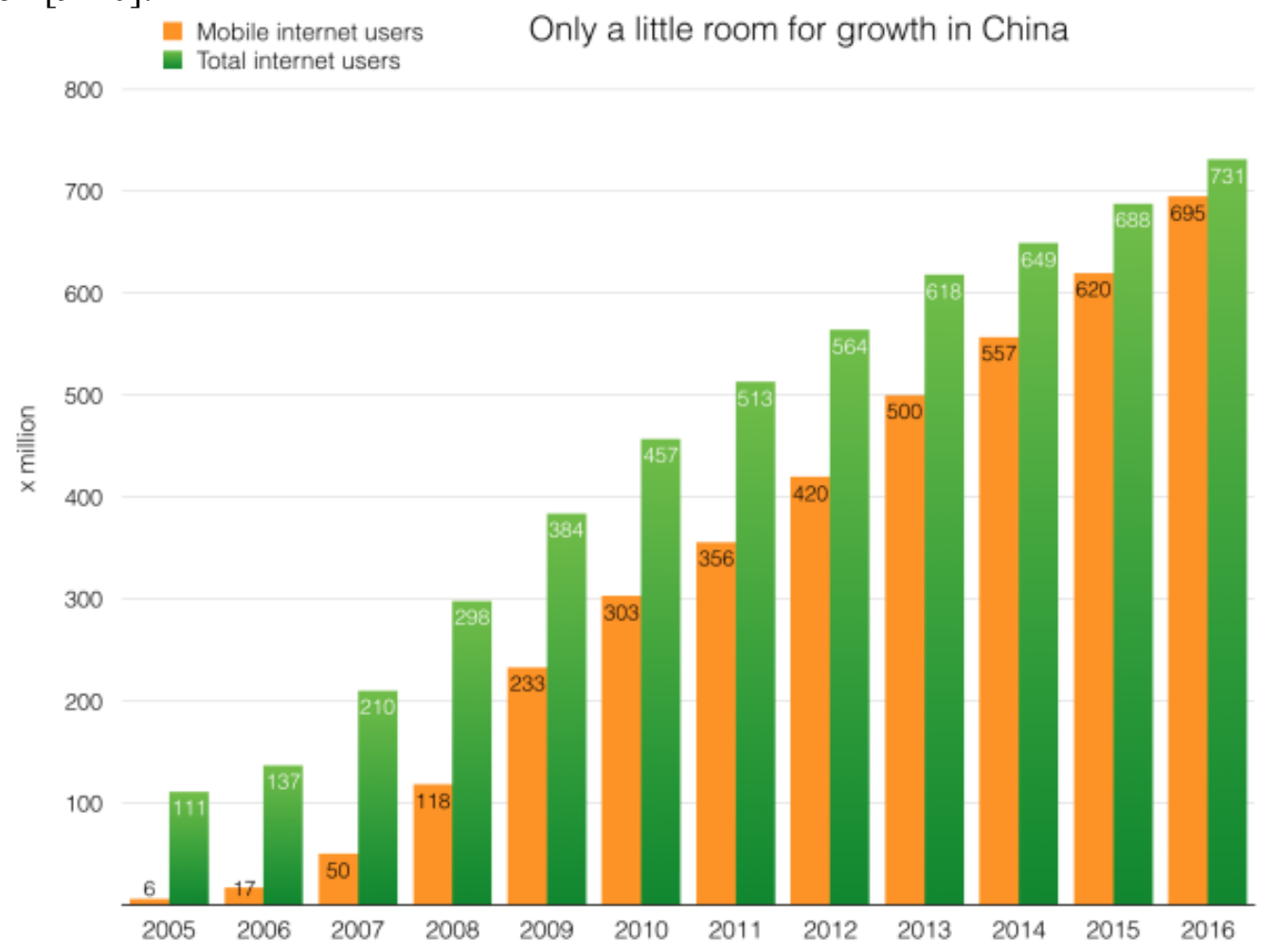

Figure 1. Finite China's Internet users development scale map

\section{The University Students' Innovation and Entrepreneurial Ability Training Process Problems}

The form of activity is greater than meaning. Students participate in innovation activities initiative and enthusiasm is not high, very inert, while students do not attach importance to the content of innovation activities, just as a means to get out of the classroom, in the whole process of innovation cannot actively access, often It is difficult to produce good innovation results, and even cannot produce results.

The Long Cycle of Innovation Activities, by the Venue and Classroom Teaching Constraints. The cycle of innovation activities is generally longer and usually takes more than a year. But also during the whole event, the need for specialized activities base, while the need to take up a lot of student energy, these conditions lead to innovation activities, time and space cannot be effectively guaranteed, reducing the enthusiasm of students to participate in activities, while learning by learning restrictions, cannot participate in practice for a long time.

The Team of Instructors Needs to be Improved. University of innovation and entrepreneurship activities of the instructors usually by counselors and a small number of professional teachers, the lack of specialized instructors. And professional teachers, although the theoretical basis of solid, but due to research direction and work constraints, the lack of practical experience of the Internet era, easy to talk on paper, from reality. At the same time, colleges and universities lack the corresponding encouragement mechanism for the innovation activities of teachers participating in the students, and cannot improve the enthusiasm of teachers' participation, which leads to the emergence of few good innovations. 


\section{"Internet plus" under the Background of College Students Innovation and Entrepreneurial Ability Training Measures}

Construction of Innovative Practice Base Platform for College Students. Relying on the "Internet plus" background to build all kinds of college students innovative practice platform, to absorb more students to participate in innovation activities. By participating in various provincial and national innovation project competition, to stimulate students' imagination, through the accumulation of experience, strengthen the platform construction, experimental innovation experience and vitality continue to inherit. With the continuous increase in innovation, will lead the students really threw himself into the innovation activities of college students, for future entrepreneurship to lay the foundation for experience and ability.

Implementing the Exchange Mechanism of Creative Credits and Course Credits. Through the establishment of the corresponding credit swap system, so that students through innovative activities to obtain a large number of innovative credits, to meet the conditions under the premise of innovation credits and curriculum credits to achieve the exchange, in order to achieve some of the professional courses exempt, so as to get more Of the time for innovative activities. Achieve the results of national innovation competition students can use innovative results instead of graduation design, and give excellent results reward. This will use the status quo of college students now, to fully mobilize the enthusiasm of students to participate in innovative activities, so that students innovative activities to achieve a virtuous circle.

The Implementation of College Students Innovation Instructor's Reward System, Improve the Construction of Teachers. College teachers should actively with the times, change the traditional teaching concepts and teaching methods, from the "Internet plus" mode of thinking, to adapt to the needs of the times, the use of the Internet to carry out business practice. At the same time, the system of rewarding teachers is improved, and the teachers 'initiative is added to the innovation activities of college students by improving the students' innovation achievement and the proportion of teachers 'assessment. The teachers' ability and the innovation activities of college students are realized in the "Internet plus" era In the common promotion.

To Achieve a Two - Way Evaluation System with the Enterprise's Ability to Students. Through the university teachers and social human resources experts to establish students' quality ability model shown in Fig. 2, the establishment of students to participate in social practice guidance system to achieve student and business two-way evaluation: the correct evaluation of the students can provide students with the ability to improve Reliable basis; student assessment of the enterprise can objectively reflect the development of enterprises, establish a positive corporate image of the enterprise. Through the "Internet plus" for large sample collection and large data statistical methods, the establishment of the whole society credit evaluation system.

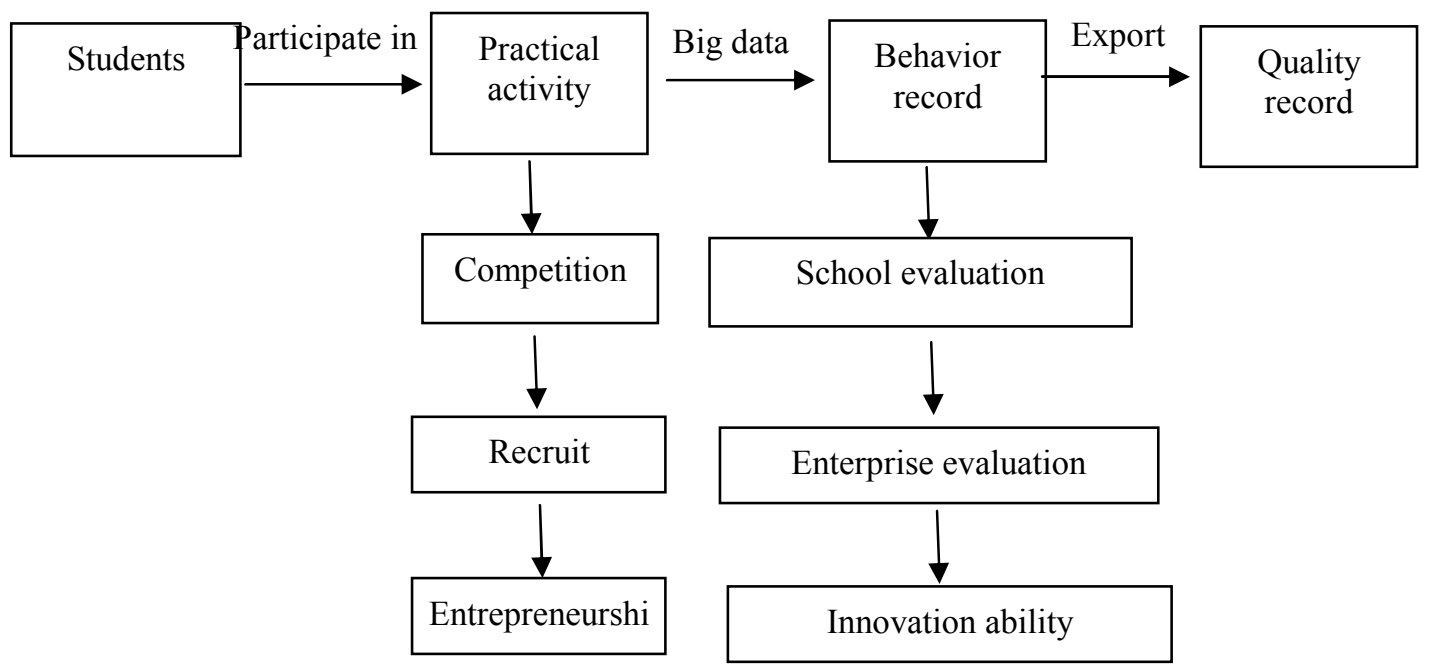

Figure 2. Finite students' quality ability model 


\section{Summary}

In summary, in the "Internet plus" era background, "Internet plus" for college students to provide a very broad entrepreneurial environment. Entrepreneurship needs to be built on the basis of innovation, the only way to enable students to avoid blind impulse business activities, improve the success rate of entrepreneurship. In the context of the "Internet plus" era, the school through the establishment of a sound innovation and entrepreneurial platform and system, through the students of innovative entrepreneurship teaching, improve students' correct entrepreneurial awareness, out of the campus into the community engaged in entrepreneurial activities in the process, to create their own new world.

\section{References}

[1] X.F. Zhang: Internet Plus National Strategic Action Road Map (Beijing China Critic Press, China 2015)

[2] S.M. Xu and W.J. Qi: Chinese Youth Social Sciences, Vol.34 (2015) No.9, P.30(In Chinese)

[3] L.X. Feng and R.H. Wang: Innovation and Entrepreneurial Ability Training (Beijing Tsinghua University Press 2013)

[4] G. F. Chen: Fundamentals of Modern Cybernetics (Machinery Industry Press, China 2014).

[5] Y. Cheng and P. Liu: Shanxi Journal of Social Sciences, Vol. 27 (2015) No.7, p.73. (In Chinese)

[6] J.L. Zhang: Modern Commerce Industry, Vol. 131 (2015) No.19, p.99.

[7] X. Yin and F.R Xi: Chinese University Science and Technology, Vol. 291 (2015) No.3, p.75. (In Chinese)

[8] X.J. Su, J. Wu and Y. Cao: Chinese University Science and Technology, Vol. 251 (2011) No.11, p.76. (In Chinese)

[9] X.F. Wang: School Party Building and Ideological Education, Vol. 328 (2013) No.1, p.73. (In Chinese)

[10] Y.Y. Mei and F. Xia: Jiangsu Higher Education, Vol. 264 (2016) No.3, p.116. (In Chinese) 